И.И. Крукиер ${ }^{1}$, В.В. Авруцкая ${ }^{1}$, М.А. Левкович ${ }^{1}$, Е.В. Нарежная ${ }^{2}$, Г.В. Смолянинов ${ }^{1}$, Л.Л. Ерджанян ${ }^{1}$, А.А. Никашина ${ }^{*}$

${ }^{1}$ Ростовский государственный медицинский университет,

Ростов-на-Дону, Российская Федерация

2 Южный федеральный университет, Ростов-на-Дону, Российская Федерация

\title{
Особенности изменения биорегуляторов
}

\section{и органических кислот в сыворотке крови}

\author{
и амниотической жидкости женщин
}

\section{со спонтанными преждевременными родами}

\begin{abstract}
Обоснование. Преждевременные роды в настоящее время являются серьезной проблемой для акушеров-гинекологов. Существует концепция патогенеза преждевременных родов с позиции метаболомных нарушений, происходящих на молекулярном уровне. Цель исследования - определить уровень биоактивных регуляторов и органических кислот у пациенток с беременностью, закончивщейся своевременными или спонтанными преждевременными родами, в сыворотке крови и амниотической жидкости и показать их роль в патогенезе прогнозирования недонашивания беременности и перинатальных исходов. Методы. Обследованы 72 женщины, из них 40 (контрольная группа) с физиологическим течением беременности, закончившейся в срок, и 32 (основная группа) с преждевременными родами. Материалом для исследования служили сыворотка крови, взятая у пациенток в первом периоде родов, и амниотическая жидкость, полученная после родов. Продукцию факторов роста TGFß и TNFа определяли методом твердофазного иммуноферментного анализа. Органические кислоты (лимонную и янтарную) определяли методом капиллярного электрофореза. Результаты. Продукция TNFа в сыворотке крови женщин со спонтанными преждевременными родами уменьшалась на $38 \%$, а уровень лимонной и янтарной кислот - на 33 и $30 \%$ соответственно по сравнению с контрольной группой, а в амниотической жидкости уженщин с данной патологией

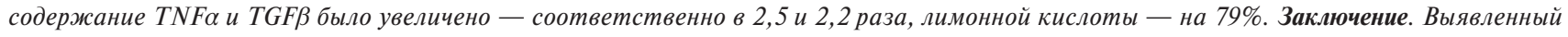
дисбаланс показателей TNF и TGFß, а также лимонной и янтарной кислот в биологических жидкостях дает возможность считать их предикторами спонтанных преждевременных родов и перинатального поражения центральной нервной системы у новорожденных. Ключевые слова: преждевременные роды, цитокины, органические кислоты.

(Для цитирования: Крукиер И.И., Авруцкая В.В., Левкович М.А., Нарежная Е.В., Смолянинов Г.В., Ерджанян Л.Л., Никашина А.А. Особенности изменения биорегуляторов и органических кислот в сыворотке крови и амниотической жидкости женщин со спонтанными преждевременными родами. Вестник РАМН. 2018;73(6):361-367. doi: 10.15690/vramn1017)
\end{abstract}

I.I. Krukier ${ }^{1}$, V.V. Avrutskaya ${ }^{1}$, M.A. Levkovich ${ }^{1}$, E.V. Narezhnaya ${ }^{2}$, G.V. Smolyaninov ${ }^{1}$, L.L. Yerdzhanyan ${ }^{1}$, A.A. Nikashina ${ }^{1^{*}}$

${ }^{1}$ Rostov State Medical University, Rostov-on-Don, Russian Federation

${ }^{2}$ Southern Federal University, Rostov-on-Don, Russian Federation

Peculiarities of Changing Bioregulators and Organic Acids in the Serum of Blood and Amniothic Fluid of Women with Spontaneous Preterm Labor

BACKGROUND: Premature birth is currently a serious problem for obstetrician-gynecologists. Most researcher consider this problem from the standpoint of metabolome disturbances. AIMS: determination of the level of bioactive regulators and organic acids with physiological and complicated pregnancy, ending in timely and spontaneous preterm labor, in blood serum and amniotic fluid and revealing the presence of their relationship for the development of premature birth and the condition of newborns. MATERIALS AND METHODS: 72 women were examined, 40 of them with a physiological pregnancy (control group) and 32 with premature labor (the main group). All studies were carried out in the blood serum and amniotic fluid of women of these groups. The content of TGF $\beta$ was determined by the method of solid-phase enzyme immunoassay. Identification and quantitative determination of citric and succinic acids were carried out by the method of capillary electrophoresis. RESULTS: TNF production in the blood serum of women with preterm labor, decreased by 38\%, and the level of citric and succinic acids by 33 and 30\%, respectively, compared with the control group. In the amniotic fluid the level of TNF $\alpha$ was increased 2.5 times and TGF -2.2 times, citric acid - $79 \%$. CONCLUSIONS: The revealed imbalance in the level of cytokines and organic acids studied in that biological fluids can evidently affect the fetal condition, which can be considered as possible markers of perinatal injuries and prognostic indicators of the state of the newborn.

Key words: premature birth, cytokines, citric acid, succinic acid.

(For citation: Krukier II, Avrutskaya VV, Levkovich MA, Narezhnaya EV, Smolyaninov GV, Yerdzhanyan LL, Nikashina AA. Peculiarities of Changing Bioregulators and Organic Acids in the Serum of Blood and Amniothic Fluid of Women with Spontaneous Preterm Labor. Annals of the Russian Academy of Medical Sciences. 2018;73(6):361-367. doi: 10.15690/vramn1017) 


\section{Обоснование}

Угроза прерывания беременности на разных сроках до сих пор остается весьма актуальной. Большинство ученых, занимающихся данной проблемой, высказывают мнение о том, что плод в какой-то степени контролирует процесс развития родовой деятельности посредством сигнала, воздействующего через существующие связи на организм матери. При ухудшении «условий обитания» плода происходит преждевременная (до срока родов) передача сигнала «бедствия» через плодные оболочки к организму матери $[1,2]$. Преждевременные роды являются патологическим процессом, и в настоящее время многими исследователями рассматриваются с позиции метаболомных нарушений, происходящих на молекулярном уровне [3]. Исследование амниотической жидкости при угрозе прерывания беременности дает основание для прогноза состояния новорожденного путем определения содержания протеиногенных аминокислот и ангиогенных факторов роста [4].

При нормальном течении беременности резервные возможности организма значительны, но любое осложнение ее свидетельствует о метаболических нарушениях в одном или нескольких звеньях системы «мать-плацента-околоплодная среда-плод». На данный момент нет сомнений, что заболевания зрелого возраста зачастую связаны с проблемами, возникшими в период внутриутробного развития [5].

Современные, высокоточные методы исследования позволили выделить наиболее значимые биологически активные пептиды, контролирующие процессы ангиогенеза, к которым относятся и цитокины.

Известно, что цитокины играют значительную роль и в процессах эмбриогенеза [6]. Важная роль цитокинов определяет их участие в межклеточных и межсистемных взаимодействиях, функциональной активности клеток, а также других процессах. К общим свойствам этих биорегуляторов относятся индуцибельность синтеза и саморегуляция их продукции, а их генерация в биологических жидкостях может изменяться как при физиологических, так и патологических состояниях [7].

В связи с развитием родовой деятельности наиболее часто исследуются провоспалительные цитокины, такие как трансформирующий фактор роста $\beta$ (transforming growth factor beta, TGF $\beta$ ) и фактор некроза опухоли $\alpha$ (tumor necrosis factor alpha, TNF $\alpha$ ).

Доказано, что основным источником энергетического обеспечения клетки является аденозинтрифосфат, ресинтез которого связан не только с окислительно-восстановительными реакциями, но и с процессом гликолиза, сопряженного в условиях нормы со скоростью функционирования цикла лимонной кислоты. Известна также роль янтарной кислоты, стимулирующей процесс поступления кислорода в клетки. Она нормализует функции всех органов и тканей, снижает уровень стресса, восстанавливает энергообмен и значительно влияет на головной мозг плода и новорожденного [8]. Эти органические кислоты используются в терапии различных осложнений беременности, особенно при наличии гипоксии и гипотрофии плода. Они также нормализуют течение осложненной гестации.

Цель исследования - определить уровень биоактивных регуляторов и органических кислот у пациенток с беременностью, закончившейся своевременными или спонтанными преждевременными родами, в сыворотке крови и амниотической жидкости и показать их роль в патогенезе прогнозирования недонашивания беременности и перинатальных исходов.

\section{Методы}

\section{Дизайн исследования}

Нами было проведено одноцентровое одномоментное контролируемое обсервационное рандомизированное исследование. Из 500 беременных, наблюдавшихся в Ростовском НИИ акушерства и педиатрии, в исследование были включены 72 женщины, отобранные случайным образом в результате простой рандомизации с использованием таблицы «случайных чисел».

Обследованы 32 пациентки со спонтанными преждевременными родами (на 30-34-й нед) и 40 с физиологическим течением беременности и родами (в 37-40 нед) и их новорожденные (рис. 1).

\section{Критерии соответствия}

\section{Критерии включения:}

- первобеременные женщины с одноплодной неосложненной беременностью без экстрагенитальной патологии (контрольная группа);

- первобеременные женщины с одноплодной, осложненной спонтанными преждевременными родами беременностью без экстрагенитальной патологии (основная группа).

\section{Критерии исключения:}

- женщины с экстрагенитальной патологией в состоянии декомпенсации, с осложненным течением гестации (преэклампсия);

- беременные, родоразрешение которых проведено оперативным путем;

- женщины, родившие детей с пороками развития.

\section{Условия проведения}

Исследование выполнялось на базе клинических и научных подразделений Научно-исследовательского института акушерства и педиатрии Ростовского государственного медицинского университета Минздрава России.

\section{Продолжительность исследования}

Исследование проводилось в период с 2017 по 2018 г.

\section{Описание медицинского вмешательства}

Все необходимые и регламентируемые приказом Минздрава России № 572н от 1 ноября 2012 «Об утверждении Порядка оказания медицинской помощи по профилю «акушерство и гинекология» (за исключением использования вспомогательных репродуктивных технологий)» исследования включали в себя клинические, клинико-лабораторные и клинико-инструментальные методы обследования

Обследование новорожденных включало оценку состояния ребенка при рождении с учетом особенностей соматического, дыхательного и неврологического статуса по шкале Апгар (Apgar). Состояние мозговой гемодинамики и тяжесть ишемии мозга определяли с помощью церебральной транскраниальной оксиметрии сразу после рождения, а также на 1; 3 и 5-е сут. Сатурация регистрировалась в течение 10-15 мин на церебральном оксиметре FORE-SIGHT (США). 


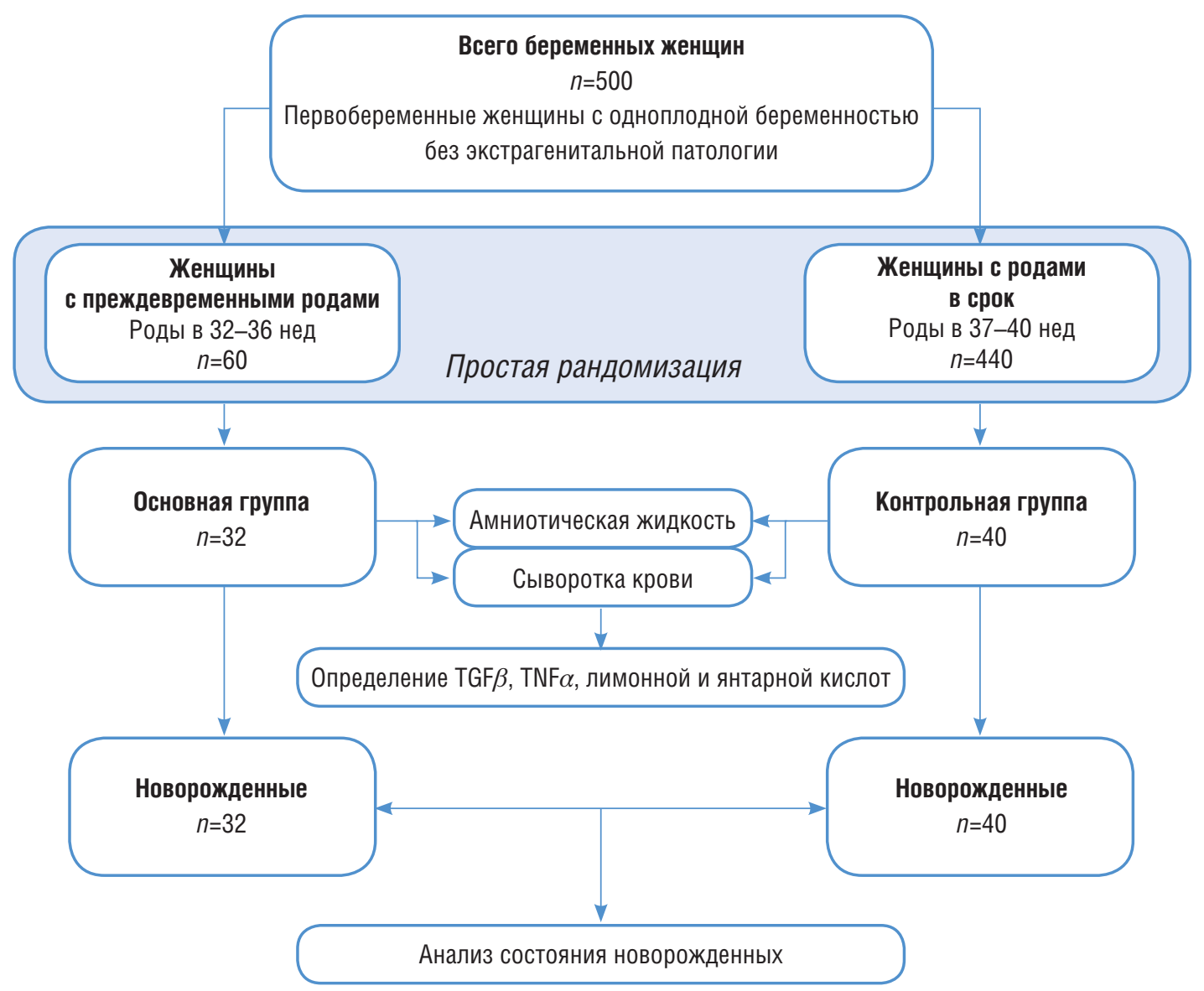

Рис. 1. Дизайн исследования

\section{Исходы исследования}

Основной исход исследования

Конечной точкой исследования явилось установление взаимосвязи между изученными показателями (TGF $\beta, \mathrm{TNF} \alpha$ и лимонной, янтарной кислотами) в амниотической жидкости и сыворотке крови беременных женщин и развитием у них спонтанных преждевременных родов, а также со степенью перинатального поражения центральной нервной системы (ЦНС) у новорожденных.

\section{Дополнительные исходы исследования}

Дополнительно проведено обследование детей, рожденных вследствие физиологических или спонтанных преждевременных родов.

\section{Анализ в подгруппах}

Обследованы 72 пациентки и их новорожденные, составившие 2 группы - контрольную и основную. В основную группу были включены первородящие первобеременные женщины, роды у которых произошли в сроки с 30-й по 34-ю нед беременности. В контрольную группу вошли первородящие первобеременные женщины, физиологические роды у которых произошли в сроки 37-40 нед.

\section{Методы регистрации исходов}

Материалом для исследования служили сыворотка крови, взятая у пациенток в первом периоде родов, и амниотическая жидкость, полученная после родов.

Содержание TGF $\beta$ и TNF $\alpha$ определяли методом твердофазного иммуноферментного анализа, используя на- боры фирм R\&D system (США) и Cytimmune systems (США), согласно рекомендациям производителя.

Концентрацию лимонной и янтарной кислоты в сыворотке крови и амниотической жидкости определяли методом капиллярного электрофореза с использованием немодифицированного кварцевого капилляра с внешней полиамидной пленкой общей длиной 60 см и внутренним диаметром 75 мкм. Время ввода пробы - 15 сек при давлении 30 Мбар, рабочее напряжение -+20 кВ; использовали прямое спектрофотометрическое детектирование при 200 нм [9]. Исследования проводили на аппарате «Капель-105» (Люмэкс, Санкт-Петербург, Россия).

Обработка полученных данных проводилась на компьютере с программным обеспечением «Мультихром» (АО «Амперсенд», Россия).

\section{Этическая экспертиза}

Исследование было одобрено Этическим комитетом Ростовского НИИ акушерства и педиатрии Минздрава России (протокол № 76/3 от 27 ноября 2017). Информированное согласие подписывали все беременные, принявшие участие в исследовании.

\section{Статистический анализ}

\section{Принципы расчета размера выборки}

Размер выборки предварительно не рассчитывался.

\section{Методы статистического анализа данных}

При проведении статистического исследования полученных данных использовались возможности пакетов прикладных программ (Мегастат и Statistica 6.0). При определении статистической обоснованности 
различия исследуемых групп применялся параметрический критерий Стьюдента (при нормальном распределении по Хи-квадрату). Данные представлены в виде среднего арифметического (M) \pm стандартная ошибка среднего арифметического (m). Максимально допустимый уровень ошибки первого рода был принят за $5 \%$ $(p=0,05)$.

Для выявления взаимосвязи между отдельными показателями использовался коэффициент корреляции, который рассчитывался по Спирмену.

\section{Результаты}

\section{Объекты (участники) исследования}

Всего были обследованы 72 пациентки, составившие 2 группы. Основную группу составили первородящие первобеременные женщины, роды у которых произошли в сроки 30-34 нед беременности $(n=32)$. В контрольную группу вошли первородящие первобеременные женщины с физиологическими родами на $38-40$-й нед $(n=40)$. Средний возраст рожениц был сопоставим в обеих группах $-25,6 \pm 0,3$ года $(p<0,05)$.

\section{Основные результаты исследования}

В результате наших исследований были выявлены статистически значимые изменения в уровнях TNF $\alpha$, лимонной и янтарной кислот в сыворотке крови пациенток (табл. 1): в группе женщин со спонтанными преждевременными родами по сравнению с группой контроля продукция TNF $\alpha$ уменьшилась на $38 \%(p<0,05)$, содержание лимонной и янтарной кислоты - на $33(p<0,05)$ и $30 \%$ $(p<0,05)$ соответственно.

В амниотической жидкости женщин с преждевременными родами (табл. 2) содержание TNF $\alpha$ и TGF $\beta$ было существенно увеличено - в 2,5 и 2,2 раза $(p<0,001)$ соответственно.

Показано также, что воздействие некоторых цитокинов на клетки и ткани может способствовать развитию системного воспаления и окислительного стресса [10]. K этим цитокинам относятся TGF $\beta$ и TNF $\alpha$, что в конечном итоге может привести к формированию эндотелиальной дисфункции, а в дальнейшем и к прерыванию беременности.
Таблица 1. Содержание цитокинов и органических кислот в сыворотке крови женщин с физиологической беременностью и преждевременными родами $(\mathrm{M} \pm \mathrm{m})$

\begin{tabular}{|l|c|c|}
\hline \multicolumn{1}{|c|}{ Показатели } & $\begin{array}{c}\text { Физиологические } \\
\text { роды }\end{array}$ & $\begin{array}{c}\text { Преждевременные } \\
\text { роды }\end{array}$ \\
\hline ТGF $\beta$, нг/мл & $0,32 \pm 0,03$ & $0,33 \pm 0,018$ \\
\hline TNF $\alpha$, нг/мл & $0,39 \pm 0,02$ & $0,24 \pm 0,021^{*}$ \\
\hline $\begin{array}{l}\text { Лимонная кислота, } \\
\text { мкг/мл }\end{array}$ & $21,12 \pm 0,89$ & $14,65 \pm 0,56^{*}$ \\
\hline $\begin{array}{l}\text { Янтарная кислота, } \\
\text { мкг/мл }\end{array}$ & $10,14 \pm 0,55$ & $7,1 \pm 0,64^{*}$ \\
\hline
\end{tabular}

Примечание. * - достоверность отличий от показателей при физиологической беременности $(p<0,05)$.

Таблица 2. Содержание цитокинов и органических кислот в амниотической жидкости женщин с физиологической беременностью и преждевременными родами $(\mathrm{M} \pm \mathrm{m})$

\begin{tabular}{|l|c|c|}
\hline \multicolumn{1}{|c|}{ Показатели } & $\begin{array}{c}\text { Физиологические } \\
\text { роды }\end{array}$ & $\begin{array}{c}\text { Преждевременные } \\
\text { роды }\end{array}$ \\
\hline TGF $\beta$, нг/мл & $0,37 \pm 0,02$ & $0,83 \pm 0,03^{*}$ \\
\hline TNF $\alpha$, нг/мл & $12,09 \pm 0,59$ & $30,94 \pm 1,47^{*}$ \\
\hline $\begin{array}{l}\text { Лимонная кислота, } \\
\text { мкг/мл }\end{array}$ & $10,17 \pm 0,31$ & $17,85 \pm 0,55^{*}$ \\
\hline $\begin{array}{l}\text { Янтарная кислота, } \\
\text { мкг/мл }\end{array}$ & $7,49 \pm 0,29$ & $9,39 \pm 1,45$ \\
\hline
\end{tabular}

Примечание. * - достоверность отличий от показателей при физиологической беременности $(p<0,05)$.

Значительное повышение уровня лимонной кислоты наблюдалось в амниотической жидкости беременных женщин основной группы (на $79 \% ; p<0,05)$ по сравнению с пациентками контрольной группы (рис. 2).

\section{Дополнительные результаты исследования}

Дополнительно был проведен анализ состояния детей, родившихся у матерей, участвующих в данном исследовании.

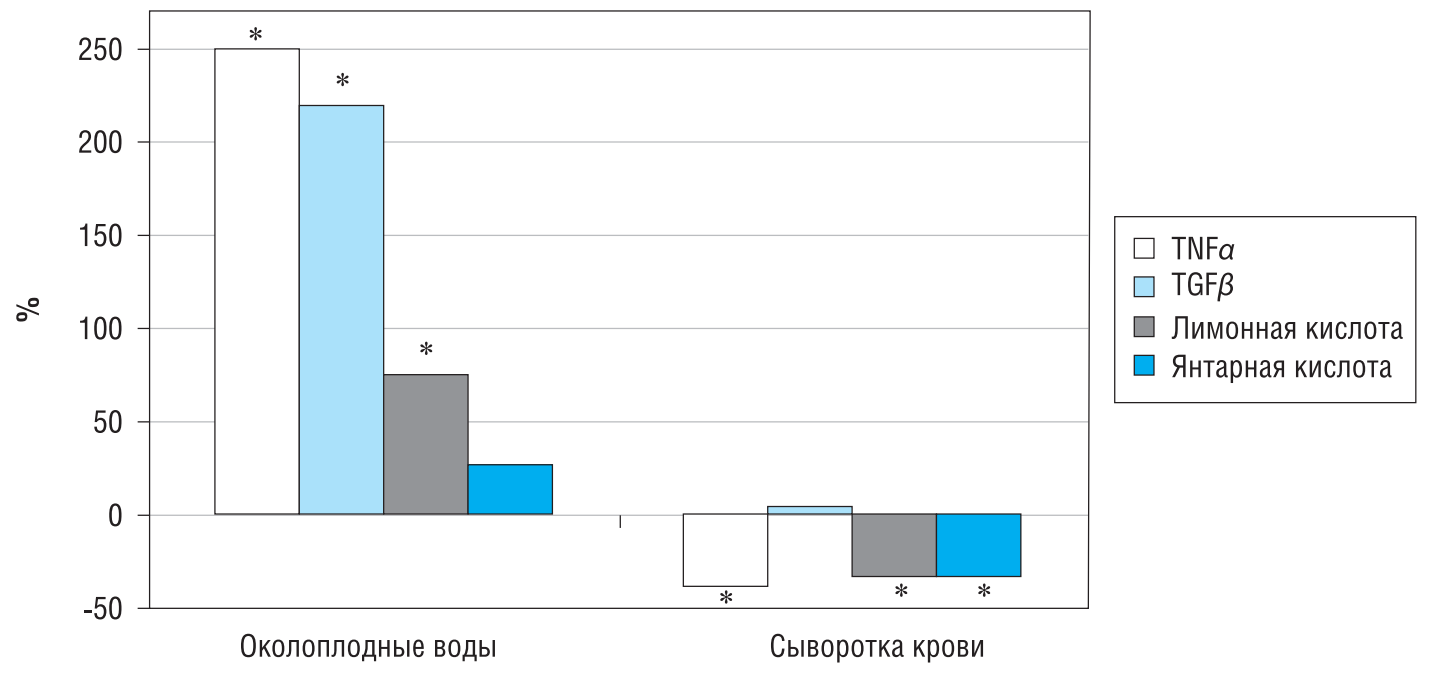

Рис. 2. Динамика цитокинов и органических кислот (в \% к контролю) в сыворотке крови и амниотической жидкости женщин с преждевременными родами

Примечание. * - достоверность отличий от показателей при физиологической беременности $(p<0,05)$. 
Среди детей, родившихся у женшин основной группы, перинатальное поражение ЦНС гипоксически-ишемического генеза имело место в $64 \%$ случаев. Были также зарегистрированы синдром угнетения (43\%), синдром мышечной дистонии по гипотоническому типу (41\%), снижение сухожильных рефлексов (50\%); отмечались рефлексы орально-спинального автоматизма (50\%). Наличие перинатального поражения ЦНС гипоксически-ишемического генеза новорожденных сочеталось с повышением $\mathrm{TNF} \alpha$ и TGF $\beta$ в амниотической жидкости в среднем в 2,3 раза $(p<0,01)$ и лимонной кислоты на $79 \%(p<0,05)$ относительно таковых в контрольной группе. В ранее проведенных нами исследованиях было установлено, что продукция TGF $\beta$ в пуповиной крови новорожденных от спонтанных преждевременных родов была увеличена на $45 \%$, TNF $\alpha$ - на 56\%, лимонной кислоты - на 36\% [11].

В этой группе матерей и их новорожденных был проведен корреляционный анализ между уровнями TNF $\alpha$ и TGF $\beta$ в амниотической жидкости и показателями нейросонографии у новорожденных. В результате проведенного анализа была выявлена тесная взаимосвязь уровня TNF $\alpha$ с размерами субарахноидального пространства мозга новорожденного $(\mathrm{r}=0,67 ; p<0,01)$ и уровня TGF $\beta$ с желудочковым индексом $(\mathrm{r}=0,78 ; p<0,01)$, что подтверждает обнаруженные различные по локализации и тяжести церебральные повреждения у новорожденных.

\section{Нежелательные явления}

Нежелательных явлений, возникших в результате проведения исследования, не отмечено.

\section{Обсуждение}

\section{Резюме основного результата исследования}

Полученные нами данные об изменении указанных цитокинов и органических кислот в сыворотке крови и амниотической жидкости женщин позволяют оценить прогностическую значимость указанных показателей: так, в сыворотке крови выявлена взаимозависимость между TNF $\alpha$ и лимонной кислотой $(\mathrm{r}=0,74 ; p<0,05)$, $\mathrm{TNF} \alpha$ и янтарной кислотой $(\mathrm{r}=0,60 ; p<0,05)$, в амниотической жидкости - между TGF $\beta$ и TNF $\alpha(\mathrm{r}=0,87 ; p<0,01)$ и TGF $\beta$ и лимонной кислотой $(\mathrm{r}=0,78 ; p<0,05)$, что позволяет более эффективно проводить лечебные мероприятия, а также использовать их в качестве дополнительных критериев для оценки состояния новорожденных.

\section{Обсуждение основного результата исследования}

Известно, что спонтанные преждевременные роды подвергают плод высокому риску поражения ЦНС ишемически-гипоксического генеза [12]. Именно неизбежные изменения в связи с ростом потребностей плода в трофике и нарушения в гемодинамике матки влекут за собой те многогранные отклонения, которые, тем не менее, имеют неспецифический характер и определяют механизм преждевременных родов [13]. Нарушение нормального течения процессов имплантации и плацентации, в регуляции которых принимают участие цитокины (TNF $\alpha$, TGF $\beta$ ) и органические кислоты (лимонная и янтарная), приводит к различным осложнениям беременности.

Как указывалось выше, содержание TNF $\alpha$ и TGF $\beta$ в амниотической жидкости пациенток с преждевременными родами было значительно выше контрольных величин. Так, известно, что TGF $\beta$ играет значимую роль в процессах имплантации, являясь одним из важных компонентов, обеспечивающих инвазию трофобласта, и повышение его содержания, по-видимому, объясняется необходимостью усиления инвазии; в то же время этот ростовой фактор - ингибитор пролиферации - блокирует клеточный рост, что пагубно сказывается на течении беременности [14]. TGF $\beta$ также относят к ключевым факторам высокой метаболической активности, стимулирующим дифференцировку клеток.

Очевидно, усиление в амниотической жидкости женщин с преждевременными родами продукции важного биорегулятора, каким является $\mathrm{TNF} \alpha$, вызывает нарушение баланса в меж- и внутриклеточной цитокиновой сети и сказывается на многих биохимических процесcax, происходящих в системе «мать-плацента-плод». Такое выраженное увеличение TGF $\beta$ и TNF $\alpha$ связано с развивающейся дискоординацией родовой деятельности при спонтанных преждевременных родах и является, по-видимому, одним из важных факторов последующего развития аномалии родового акта [14]. TNF $\alpha$ способен также индуцировать активность фосфолипазы $\mathrm{A}_{2}$, тем самым ускоряя последовательность биохимических реакций арахидоновой кислоты, приводящих к модификации синтеза простагландинов и сократительной активности матки. Эти нарушения связаны, вероятно, с выраженным метаболическим дисбалансом, наблюдаемым у пациенток со спонтанными преждевременными родами [15].

Показано также, что провоспалительные цитокины, к которым относятся TNF $\alpha$ и TGF $\beta$, стимулируют адаптивный иммунитет и модулируют регуляцию Т-клеток и индукцию толерантности к ним [16].

Следует отметить, что в сыворотке крови у пациенток с преждевременными родами содержание TNF $\alpha$ достоверно уменьшалось. Интерес представляет тот факт, что $\mathrm{TNF} \alpha$, как известно, вызывающий апоптоз (при высоком его уровне), способен при определенных условиях (уменьшение его продукции) защищать эндотелиальные клетки от апоптоза и тем самым увеличивать их жизнеспособность [17].

Что касается содержания лимонной и янтарной кислот, то они также достоверно снижались в сыворотке крови и, напротив, повышались в амниотической жидкости у данных пациенток. Известно, что изученные нами органические кислоты (лимонная и янтарная) обладают антигипоксическими и антиоксидантными свойствами [18]. Они способны активировать функции органов и тканей, повышать реактивность организма, улучшать течение и исход гестации и обеспечивать рост и развитие плода.

Избыток или недостаток продукции изученных цитокинов может быть одним из звеньев патогенеза данного осложнения гестации, а выявленный дисбаланс в сывороточном и локальном уровнях органических кислот (лимонной и янтарной) подтверждает эту гипотезу.

Следует заключить, что метаболические профили амниотической жидкости и материнской сыворотки крови являются источниками ценной информации о развитии плода и могут быть полезны при диагностике нарушений беременности [19].

Известно также, что повышение уровня TNF $\alpha$ в среде, окружающей эмбрион, может иметь существенное воздействие на развивающийся мозг, приводить к нарушению проницаемости гематоэнцефалического барьера и появлению неврологической симптоматики в период новорожденности [20]. Выраженный дисбаланс в уровне изученных цитокинов в сыворотке крови и амниотической жидкости можно объяснить еще и тем, что TNF $\alpha$, являясь одним из цитокинов, опосредованно контроли- 
рующих открытие кальциевых каналов, изменяет продукцию кальция при развившейся слабости родовых сил и влияет на физиологическое соотношение внеклеточного и внутриклеточного $\mathrm{Ca}^{2+}[21]$, что вызывает нарушение сократительной активности миометрия у женщин со спонтанными преждевременными родами.

Нами был проведен корреляционный анализ с целью выявления взаимосвязи и взаимозависимости между изученными показателями (биорегуляторами и органическими кислотами) в сыворотке крови и амниотической жидкости обследованных пациенток. В результате получены следующие коэффициенты корреляции: в сыворотке крови - между TNF $\alpha$ и лимонной кислотой $(\mathrm{r}=0,74$; $p<0,05), \mathrm{TNF} \alpha$ и янтарной кислотой $(\mathrm{r}=0,60 ; p<0,05)$; в амниотической жидкости - между ТGF $\beta$ и ТNF $\alpha$ $(\mathrm{r}=0,87 ; p<0,01), \mathrm{TGF} \beta$ и лимонной кислотой $(\mathrm{r}=0,78$; $p<0,05)$. Можно предполагать, что выявленные нами взаимозависимости, приводящие к дисбалансу регуляторных процессов и компенсаторных механизмов, определяют исход беременности, а в последующем - и состояние новорожденного.

\section{Ограничения исследования}

К ограничениям исследования необходимо отнести тот факт, что все пациентки наблюдались в Ростовском НИИ акушерства и педиатрии и были представительницами Южного федерального округа. Результаты данного исследования могут быть значимыми на региональном уровне.

\section{Заключение}

Гестационный процесс находится под строгим контролем экспрессии цитокинов, в том числе и факторов роста. В этот период (имплантации, плацентации, эмбриогенеза) имеет место высокий уровень ангиогенеза, пролиферации и дифференцировки клеток.

Увеличение экспрессии TNF $\alpha$ и TGF $\beta$ в маточно-плацентарном комплексе приводит к стимуляции продукции простагландинов $\mathrm{E}_{2}$ и $\mathrm{F}_{2} \alpha$, которые являются непосредственными индукторами и регуляторами сократительной активности матки, что в свою очередь сопровождается развитием родовой деятельности.

Нами обнаружено многократное усиление продукции $\mathrm{TNF} \alpha$ и TGF $\beta$ (в среднем в 2,3 раза) и содержания лимонной кислоты (в 1,8 раза) в амниотической жидкости, с одной стороны, и уменьшение TNF $\alpha$ (в 1,6 раза), лимонной и янтарной кислот (в среднем в 1,4 раза) в сыворотке крови - с другой, что, по-видимому, способно вызвать отрицательные последствия вплоть до критических состояний в ранние сроки, а также прерывания беременности на 32-34-й нед гестации.

Выявленный дисбаланс между изученными биорегуляторами (TNF $\alpha$ и TGF $\beta$ ) и органическими кислотами (лимонной и янтарной), участвующими в метаболическом обеспечении беременности и родов, по-видимому, сопровождается истощением компенсаторно-приспособительных возможностей организма беременной и способствует развитию спонтанных преждевременных родов.
Несмотря на разнонаправленные изменения $\mathrm{TNF} \alpha$ и TGF $\beta$ и органических кислот как на локальном, так и системном уровнях, проведенный корреляционный анализ позволил обозначить и специфику выявленных связей, и определенные маркеры, позволившие прогнозировать спонтанные преждевременные роды и состояние ЦНС у новорожденных.

Нередко исход повреждений ЦНС у новорожденных зависит не только от локализации и тяжести патологического процесса, но и от ранней диагностики церебральных расстройств и своевременной терапии. Так, нами обнаружено наличие ишемии мозга 1-й степени в 58,2\% случаев и 2-й степени - в 41,8\% у новорожденных от спонтанных преждевременных родов.

С учетом выявленных патогенетических механизмов критериями ранней диагностики спонтанных преждевременных родов и перинатального поражения ЦНС у новорожденных можно рассматривать высокие уровни ТNF $\alpha$ ( $>12,7$ нг/мл), ТGF $\beta$ (>0,4 нг/мл) и лимонной кислоты (>10,5 мкг/мл) в амниотической жидкости.

В ранее проведенных нами исследованиях была установлена высокая продукция TGF $\beta$, TNF $\alpha$ и лимонной кислоты в пуповиной крови новорожденных от спонтанных преждевременных родов. Проведенный корреляционный анализ между изученными показателями в пуповинной крови и показателями нейросонограммы обнаружил достаточно высокую корреляционную связь уровня TNF $\alpha$ с размерами субарахноидального пространства мозга новорожденного $(\mathrm{r}=0,65), \mathrm{TGF} \beta-\mathrm{c}$ желудочковым индексом $(\mathrm{r}=0,64)$.

Таким образом, модификация полученных соотношений (биорегуляторов и органических кислот) в изученных жидкостях позволяет рассматривать их в качестве предикторов преждевременных родов, а также дает возможность для прогноза неврологических повреждений у детей раннего возраста.

\section{Дополнительная информация}

Источник финансирования. Исследование выполнено в рамках НИР «Определение клинико-диагностических маркеров формирования тяжелых форм акушерской патологии» (2017-2020), финансирование за счет средств госзадания № 056-00144-18-00 от 26.12.2017.

Конфликт интересов. Авторы данной статьи подтверждают отсутствие конфликтов интересов, связанных с публикацией настоящей рукописи.

Участие авторов: концепция и дизайн исследования Крукиер И.И., Авруцкая В.В.; сбор и обработка материала - Нарежная Е.В., Смолянинов В.Г., Ерджанян Л.Л.; статистическая обработка данных - Никашина А.А.; анализ полученных данных, написание текста статьи Крукиер И.И., Левкович М.А., Авруцкая В.В. Все авторы внесли существенный вклад в проведение исследования и подготовку статьи, прочили одобрили финальную версию перед публикацией.

\section{ЛИТЕРАТУРА}

1. Алеев И.А. Преждевременный разрыв плодных оболочек. Информационное письмо / Под ред. Радзинского В.Е., Ордиянц И.М. - М.: StatusPraesens; 2011. [Aleev IA. Prezhdevremennyi razryv plodnykh obolochek. Informatsionnoe pis'mo. Ed by
Radzinskii V.E., Ordiyants I.M. Moscow: Status Praesens; 2011. (In Russ).]

2. Левкович М.А., Линде В.А., Андреева В.О., и др. Иммуногормональные взаимодействия в генезе невынашивания беремен- 
ности ранних сроков // Акушерство и гинекология. - 2012. №8-1 - C. 10-14. [Levkovich MA, Linde VA, Andreeva VO, et al. Immuno-hormonal interactions in genesis of early pregnancy loss. Akusherstvo i ginekologiya. 2012;(8-1):10-14. (In Russ).]

3. Погорелова Т.Н., Гунько В.О., Никашина А.А., и др. Посттрансляционная модификация и дифференциальная экспрессия белков при плацентарной недостаточности // Проблемы репродукции. - 2016. - T.22. - №6 - C. 115-119. [Pogorelova TN, Gunko VO, Nikashina AA, et al. Post-translational modifications and differential expression of proteins in placental insufficiency. Problemy reproduktsii. 2016;22(6):115-119. (In Russ).] doi: 10.17116/ repro2016226115-119.

4. Крукиер И.И., Авруцкая В.В., Нарежная Е.В., и др. Нарушения продукции протеиногенных аминокислот, ангиогенных факторов роста и их значение в перинатальном поражении центральной нервной системы у новорожденных // Таврический медико-биологический вестник. - 2016. - Т.19. - №2 C. 89-92. [Krukier II, Avrutskaya VV, Narezhnaya EV, et al. Breach of production proteinogenic amino acids, angiogenic growth factors and their value in perinatal damage of central nervous system in newborns. Tavricheskiy mediko-biologicheskiy vestnik. 2016;19(2):89-92. (In Russ).]

5. Barker DJ. The developmental origins of adult disease. J Am Coll Nutr 2004;23(6 Suppl):588S-595S. doi: 10.1080/07315724.2004.10719428.

6. Погорелова Т.Н., Линде В.А., Крукиер И.И., и др. Молекулярные механизмы регуляции метаболических процессов в плаценте при физиологически протекающей и осложненной беременности. СПб.: Гиппократ; 2012. 304 с. [Pogorelova TN, Linde VA, Krukiyer II, et al. Molekulyarnye mekhanizmy regulyatsii metabolicheskikh protsessov $v$ platsente pri fiziologicheski protekayushchei $i$ oslozhnennoi beremennosti. St. Petersburg: Gippokrat; 2012. 304 p. (In Russ).]

7. Сельков С., Павлов О. Роль маточно-плацентарных макрофагов в репродуктивной патологии // Журнал акушерства и женских болезней. - 2010. - T.59. - №1 - C. 122-130. [Selkov S, Pavlov O. The roles of uteroplacental macrophages in reproductive pathologies. Zhurnal akusherstva i zhenskikh boleznei. 2010;59(1);122-130. (In Russ).]

8. Chinopoulos $\mathrm{C}$. Which way does the citric acid cycle turn during hypoxia? The critical role of $\alpha$-ketoglutarate dehydrogenase complex. J Neurosci Res. 2013;91(8):1030-1043. doi: 10.1002/jnr.23196.

9. Нарежная Е.В., Крукиер И.И., Авруцкая В.В., и др. Определение глутаминовой кислоты в биологическом материале методом капиллярного зонного электрофореза // Биомедицинская химия. - 2015. - T.61. - №5 - C. 628-631. [Narezhnaya EV, Krukier II, Avrutskaya VV, et al. Determination of glutamic acid in biological material by capillary electrophoresis. Biomeditsinskaya khimiya. 2015;61(5);628-631. (In Russ).] doi: 10.18097/PBMC20156105628.

10. Torres-Cuevas I, Parra-Llorca A, Sánchez-Illana A, et al. Oxygen and oxidative stress in the perinatal period. Redox Biol. 2017;12:674-681. doi: 10.1016/j.redox.2017.03.011.

11. Левкович М.А., Крукиер И.И., Кравченко Л.В., и др. Состояние цитокинового статуса у новорожденных с перинатальным гипоксически-ишемическим поражением ЦНС от матерей с хронической плацентарной недостаточностью, осложненной синдромом задержки развития плода // Российский иммунологический журнал - 2016. - Т.10. - №2-1 - C. 234-235. [Levkov- ich MA, Krukier II, Kravchenko LV, et al. The state of cytokine status in newborns with perinatal hypoxic-ischemic CNS damage from mothers with chronic placental insufficiency complicated by fetal growth retardation syndrome. Russian journal of immunology. 2016;10(2-1):234-235. (In Russ).]

12. Goda N, Kanai M. Hypoxia-inducible factors and their roles in energy metabolism. Int J Hematol. 2012;95(5):457-463. doi: 10.1007/s12185012-1069-y.

13. Милованов А.П., Лебеденко Е.Ю., Михельсон А Ф. Пути снижения акушерских потерь // Акушерство и гинекология. - 2012. №4-1 - C. 74-78. [Milovanov AP, Lebedenko EYu, Mikhelson AF. Ways of reducing obstetric losses. Akusherstvo $i$ ginekologiya. 2012;(4-1):74-78. (In Russ).]

14. Друккер Н.А., Ермолова Н.В., Авруцкая В.В., и др. Влияние изменений клеточных биоактивных вешеств амниотической жидкости на формирование задержки роста плода и развитие преждевременных родов // Российский вестник акушера-гинеколога. - 2017. - T.17. - №6 - C. 14-18. [Drukker NA, Ermolova NV, Avrutskaya VV, et al. Impact of changes in cellular bioactive substances of amniotic fluid on the development of fetal growth restriction and preterm labor. Rossiiskii vestnik akushera-ginekologa. 2017;17(6):14-18. (In Russ).] doi: 10.17116/rosakush201717614-18.

15. Pandey M, Chauhan M, Awasthi S. Interplay of cytokines in preterm birth. Indian J Med Res. 2017;146(3):316-327. doi: 10.4103/ijmr. IJMR 162414.

16. Левкович М.А., Афонин А.А., Левкович А.Ю., и др. Оценка цитокинового баланса околоплодных вод беременных с плацентарной недостаточностью при ранней и отсроченной манифестации церебральной патологии у их новорожденных // Российский иммунологический журнал. - 2017. - Т.11. - №3 C. 408-410. [Levkovich MA, Afonin AA, Levkovich AY, et al. Evaluation of cytokine balance of amniotic fluid in pregnant women with placental insufficiency in early and delayed manifestation of cerebral pathology in their newborns. Russian journal of immunology. 2017;11(3):408-410. (In Russ).]

17. Kinnunen K, Piippo N, Loukovaara S, et al. Lysosomal destabilization activates the NLRP3 inflammasome in human umbilical vein endothelial cells (HUVECs). J Cell Commun Signal. 2017;11(3):275279. doi: 10.1007/s12079-017-0396-4.

18. Смирнов А.В., Нестерова О.Б., Голубев Р.В. Янтарная кислота и ее применение в медицине. Часть II. Применение янтарной кислоты в медицине // Нефрология. - 2014. - Т.18. - №4 C. 12-24. [Smirnov AV, Nesterova OB, Golubev RV. Succinic acid and its application in medicine. Part II. Application of succinic acid in medicine. Nephrology. 2014;18(4):12-24. (In Russ).]

19. Orczyk-Pawilowicz M, Jawien E, Deja S, et al. Metabolomics of human amniotic fluid and maternal plasma during normal pregnancy. PLoS One. 2016;11(4):e0152740. doi: 10.1371/journal.pone.0152740.

20. Lehnardt S. Innate immunity and neuroinflammation in the CNS: the role of microglia in toll-like receptor-mediated neuronal injury. Glia. 2010;58(3):253-263. doi: 10.1002/glia.20928.

21. Sadlonova V, Franova S, Dokus K, et al. Participation of $\mathrm{BKCa}^{2+}$ and KATP potassium ion channels in the contractility of human term pregnant myometrium in vitro conditions. J Obstet Gynaecol Res. 2011;37(3):215-221. doi: 10.1111/j.1447-0756.2010.01340.x.

\section{КОНТАКТНАЯ ИНФОРМАЦИЯ}

*Никашина Анастасия Александровна, к.б.н., н.с. [Anastasiya A. Nikashina, PhD]; Адрес: 344012, ул. Мечникова, д. 43, Ростов-на-Дону, Россия [address: 43, Mechnikova street, 344012 Rostov-on-Don, Russia]; тел.: +7 (863) 227-50-77; e-mail: laigash@yandex.ru, SPIN-код: 6693-3430, ORCID: https://orcid.org/0000-0001-8099-9093

Крукиер Ирина Ивановна, д.б.н., в.н.с. [Irina I. Krukier, MD PhD]; e-mail: biochem@rniiap.ru, SPIN-код: 4975-1350 ORCID: https://orcid.org/0000-0003-4570-6405

Авруцкая Валерия Викторовна, д.м.н., доцент, гл.н.с. [Valeria V. Avrutskaya, MD, PhD, Assistant professor]; e-mail: v.avrutskaya@rniiap.ru, SPIN-код: 9495-9702, ORCID: https://orcid.org/0000-0001-6399-5007

Левкович Марина Аркадьевна, Д.м.н., доцент, в.н.с. [Marina A. Levkovich, MD, PhD, Assistant professor]; e-mail: xlma@mail.ru, SPIN-код: 2964-0480, ORCID: https://orcid.org/0000-0001-8047-7148

Смолянинов Георгий Валентинович, к.м.н. [Georgii V. Smolianinov, MD, PhD], зав. родильным отделением; e-mail: smolianinov.g.v@gmail.com, SPIN-код: 1849-3132, ORCID: https://orcid.org/0000-0003-4145-4255

Ерджсанян Лиана Левоновна, м.н.с. [Liana L. Yerdzhanian]; e-mail: docerdzhanian@gmail.com, SPIN-код: 3558-9049, ORCID: https://orcid.org/0000-0003-1821-0850

Нарежная Елена Васильевна, к.Х.н., доцент [Elena V. Narezhnaya, PhD]; e-mail: evn@sfedu.ru, SPIN-код: 6054-9140, ORCID: https://orcid.org/0000-0001-5381-8728 